JAHRBUCH DES STAATLICHEN INSTITUTS FÜR MUSIKFORSCHUNG

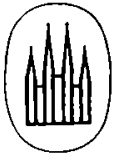





\section{Jahrbuch des Staatlichen Instituts für Musikforschung Preußischer Kulturbesitz}

1970

Herausgegeben von Dagmar Droysen

Verlag Merseburger Berlin 
Edition Merseburger 1442

(C) 1971 Verlag Merseburger Berlin GmbH Alle Rechte vorbehalten . Printed in Germany Druck: Amo Brynda, Berlin

ISBN $387537004 \mathrm{X}$ 